\title{
EVALUASI TATAKELOLA TEKNOLOGI INFORMASI DI PD BPR BANK BAPAS 69 MAGELANG MENGGUNAKAN ITIL V3 DOMAIN SERVICE STRATEGY
}

\author{
Yanuar Priatama ${ }^{1}$, Adi Nugroho ${ }^{2}$, Melkior N. N. Sitokdana ${ }^{3}$ \\ 1),2),3 ) Sistem Informasi, Fakultas Teknologi Informasi, Universitas Kristen Satya Wacana \\ Jl. Dr. O. Notohamidjojo No. 1-10, Salatiga \\ 682012010@student.uksw.edu
}

\begin{abstract}
ABSTRAK
Berbagai organisasi menggunakan teknologi informasi untuk menunjang aktivitas bisnisnya namun dalam penerapannya masih dijumpai persoalan-persoalan, maka itu dibutuhkan tata kelola teknologi informasi yang baik agar organisasi dapat eksis dan bersaing dengan pesaingnya. Salah satu BPR Bank Bapas 69 Magelang menggunakan teknologi informasi dengan memiliki tingkat kepercayaan dan keamanan sangat diharapkan oleh nasabah BPR Bank Bapas 69 Magelang, maka manajemen Sistem Informasi secara keseluruhan perlu diperhatikan mulai dari perencanaan hingga implementasi agar sistem informasi yang dihasilkan sesuai dengan tujuan perusahaan. Penelitian ini menggunakan metode deskriptif kualitatif dan framework ITIL v3 sebagai acuan dan panduan untuk menerapkan praktek terbaik yang telah diakui. Analisa berfokus pada sistem informasi perkreditan yang digunakan oleh PD BPR Bank Bapas 69 Magelang Cabang Selatan menggunakan framework ITIL v3 domain strategi layanan dan proses yang terdapat didalamnya yaitu manajemen portfolio, manajemen keuangan dan manajemen permintaan. Analisis strategi layanan terhadap sistem informasi sudah dikelola dengan baik, namun masih diperlukan pemeliharaan secara berkala agar manfaatnya lebih efektif.
\end{abstract}

Keyword : Analisis Sistem Informasi Perkreditan, ITIL v3, Strategi Layanan.

\section{PENDAHULUAN}

Perkembangan Teknologi Informasi yang semakin canggih dan tersedia pada abad ini mengubah aktivitas hidup manusia menjadi lebih efektif,efisien dan cepat. Dampak dari perkembangan tersebut membuat berbagai informasi disegala bidang bertumbuh dan berkembang menjadi lebih baik dari sisi kuantitas maupun kualitasnya. Pada era saat ini kebutuhan akan informasi sangat tinggi, oleh karena itu perlu dikembangkan berbagai fasilitas teknologi informasi dan pengelolaan yang baik (Good Governance) supaya dapat memberikan nilai tambah bagi organisasi. Setidaknya proses dan layanan Teknologi Informasi di implementasikan, dikelola dan didukung dengan cara yang tepat akan membuat organisasi akan memiliki keunggulan kompetitif, meminimalisir risiko, menghemat waktu dan biaya, meningkatkan hubungan baik dengan pelanggan. Berbagai organisasi menggunakan teknologi informasi untuk menunjang aktivitas bisnisnya namun dalam penerapannya masih dijumpai berbagai persoalan-persoalan, oleh karena itu dibutuhkan tata kelola teknologi informasi yang baik agar organisasi dapat eksis dan bersaing dengan pesaingnya.

Sebagai perusahaan yang telah menggunakan sistem informasi pada BPR Bank Bapas 69 Magelang merupakan bank BUMD yang bergerak dibidang keuangan. BPR Bank Bapas 69 Magelang mempunyai tugas menghimpun dana, menyalurkan dana dan mampu mengutamakan kepuasan nasabah. Oleh karena itu Bapas 69 Magelang harus bisa melakukan kegiatan perbankan yang prima dan didukung oleh sumber daya manusia yang profesional dengan melakukan tatakelola perusahaan yang baik, dengan palayanan pada usaha kecil dan menengah. Manfaat sistem informasi sangat penting untuk menunjang kinerja dan pelayanan kepada nasabah tidak hanya dalam bentuk pelayanan transaksi penyimpanan maupun pengambilan uang tetapi juga dalam bentuk peminjaman dan pengembalian uang. Memberikan kredit merupakan salah satu usaha Bank Bapas 69 Magelang dalam menunjang peningkatan ekonomi masyarakat. Hal ini memaparkan perkembangan penyaluran Kredit Usaha Rakyat dengan pinjaman modal bunga kecil, dan tingkat permohonan dana pinjaman meningkat, membuat petugas bank perlu bekerja secara cepat dan tepat dalam proses pencairan dana peminjaman demi keuntungan perusahaan serta pemenuhan permintaan nasabah. Tingkat kepercayaan dan keamanan sangat diharapkan oleh nasabah BPR Bank 69 Magelang itu sendiri, maka dari hal tersebut manajemen sistem informasi secara keseluruhan perlu diperhatikan mulai dari perencanaan hingga implementasi agar sistem informasi yang dihasilkan sesuai dengan tujuan perusahaan, kemudian untuk menjawab itu maka menggunakan ITIL merupakan salah satu Best Practices secara khusus domain Service Strategy, dengan harapan memberikan arahan strategis kepada manajemen perusahaan dalam mengelola layanan sistem informasinya dengan tepat guna tanpa mengabaikan segi efektifitas pada biaya.

Pada latar belakang yang ada maka diperlukan analisis sistem informasi Perkreditan di Bank Bapas 69 Magelang yang nantinya diharapkan dapat Copyright (c) 2019 Jurnal Mnemonic 
memberikan masukan untuk pihak-pihak yang ditunjuk oleh perusahaan untuk pengambilan keputusan guna peningkatan pelayanan dalam proses bisnis. Penelitian mengutamakan pada bagaimana melakukan analisis terhadap sistem informasi perkreditan di BPR Bank Bapas 69 Magelang menggunakan framework ITIL V3 mencakup domain Service Strategy beserta prosesproses yang terjadi di dalamnya yaitu Service Portfolio Management, Financial Management, dan Demand Management. Dengan Service Strategy digunakan sebagai panduan untuk menentukan tujuan/ sasaran serta ekspetasi, memiliki prioritas berbagai rencana perbaikan operasional maupun organisasional didalam organisasi TI. Organisasi TI saat ini telah mengimplementasikan Service Strategy, sebagaimana digunakan panduan untuk melakukan review strategi bagi semua proses dan perangkat aturan beserta pendukung di organisasi untuk meningkatkan kapabilitas dari semua proses di dalam Service Strategy tersebut.

\section{TINJAUAN PUSTAKA}

Penelitian yang berkaitan tentang Tata Kelola TI menggunakan ITIL V3 Domain Service Strategy bukan merupakan penelitian yang baru, banyak dilakukan seperti penelitian yang dilakukan oleh Oktoviani, Manuputty (2012) yang berjudul "Perkreditan Menggunakan Framework ITIL V.3 Domain Service Strategi (Service Portfolio Management, Financial Management dan Demand Management) di PT Bank Rakyat Indonesia (Persero) Tbk., Unit Beteleme. Penelitian tersebut bertujuan memanfaatkan layanan sistem perkreditan disuatu bank yang diikuti dengan manajemen layanan. Memberikan manfaat dan keuntungan yang berarti bagi kelangsungan aktifitas bisnis perusahaan serta memberikan manajemen layanan yang dikelola dengan baik, yang dihasilkan dari penelitian tersebut ITIL dapat memberikan arahan kepada manajemen perusahaan dalam mengelola layanan sistem informasi yang berkualitas dan sesuai dengan tujuan bisnis perusahaan tanpa melupakan segi efektifitas dari biaya yang dikeluarkan. Pengeluaran biasa dapat diperkecil karena adanya keserasian antara bisnis dan layanan TI yang digunakan, adapun peningkatan layanan dan proses dapat dilakukan sejak awal siklus hidup layanan TI itu sendiri [1].

Penelitian berikutnya dilakukan oleh Utami, Darwiyanto, Asror (2016) berjudul "Audit Infrastruktur Teknologi Informasi dengan Standar Information Technology Infrastructure Library (ITIL) V.3

Domain Service Strategy dan Service Design (Studi Kasus : I-gracias)". Penelitian ini bertujuan untuk mengukur kematangan I-gracias sebagai salah satu sarana palayanan civitas akademika dan harus memiliki kematangan yang tinggi, maka dilakukan lah proses audit dan dapat menghasilkan kepuasan layanan pada I-gracias untuk penggunanya. Kemudian yang dihasilkan dari penelitian ini merupakanpeniliaian penggunaan I-gracias untuk mahasiswa dan dikatakan bersifat netral terhadap kepuasan penggunaan[2].

Penelitian berikutnya dilakukan oleh Bata, Manuputty (2017) dengan judul "Analisis Layanan Manajemen Teknologi Informasi dengan Service Strategy ITIL V.3 (Studi Kasus: Fakultas Ilmu Kesehatan UKSW)". Tujuan dari penelitian ini untuk meningkatkan kualitas layanan teknologi informasi dilingkungan organisasi yang lebih efektif dan efisien.Dapat memberikan hasil menciptakan nilai layanan yang didukung dengan penentuan prioritas layanan yang ada pada aspek pengembangan manajemen layanan sebagai aset strategi di fakultas ilmu kesehatan UKSW[3].

Technologi Information saat ini sangat berkembang dimasyarakat umumnya merupakan sebuah teknologi yang dipergunakan untuk mengelola data, meliputi didalamnya : memproses, mendapatkan, menyusun, menyimpan, memanipulasi data dengan berbagai macam cara dan prosedur guna menghasilkan informasi yang berkualitas dan bernilai guna tinggi [4]. Menurut Haag \&Keen (1996) TI meruapakan seperangkat alat yang membantu pekerjaan dengan informasi serta melakukan tugas-tugas yang berhubungan dengan pemprosesan informasi [5].

Tata kelola TI merupakan bagian integral dari Good Corporate Governance, sebagaimana yang diketahui sebagai isu teknologi melainkan yang benar merupakan isu bisnis. Tata kelola TI lebih menyangkut mekanisme untuk menyampaikan nilai, kinerja dan mitigasi risiko, dengan berfokus pada dimana dan bagaimana keputusan yang diambil, oleh siapa, keputusan apa dan mengapa.

Tata kelola teknologi informasi adalah pertanggung jawaban dengan direksi dan manajemen eksekutif. Hal ini merupakan bagian yang terintegrasi dengan tata kelola perusahaan dan berisi kepemimpinan dan struktur serta proses organisasi, yang menjamin bahwa organisasi teknologi informasi mengandung dan mendukung strategi serta tujuan bisnis [6].

Information Technology Infrastructure Library (ITIL) merupakan kumpulan best practice untuk Information Technology Service Management (ITSM) yang merupakan panduan proses-proses tentang layanan TI yang terdapat dalam organisasi. Keuntungan penerapan ITIL berdasarkan The art of Service ITSM yang dikutip oleh farida dari ITSM.

Berikut adalah domain pada Life Cycle ITIL Version 3 [1]:

Service Strategy pada tahap ini memberikan panduan dalam merancang mengembangkan dan menerapkan manajemen layanan TI sebagai sumber daya strategis bagi organisasi. Prinsip-prinsip strategi layanan yang akan diambil dalam pengimplementasian sistem, mempertimbangkan 
visi organisasi ke depan, serta strategi untuk bertahan di tengah kompetisi. Proses -proses inti dari Service Strategy antara lain : Service Portofolio Management, Financial Management, Demant Management.

Service Design memberikan panduan untuk mendesain sistem yang tepat, inovatif, termasuk arsitektur, proses, kebijakan dan dokumentasi guna memenuhi kebutuhan organisasi saat ini dan masa yang akan dating, dan proses - proses inti yang mencakup: Service Catalog Management, Service Level, Supplier Management, Capacity Management, Availability Management, IT Service Continuity Management, Information Security Management.

Service Transition panduan untuk mengetahui kebutuhan apa saja yang akan diperlukan untuk direalisasikan dilangkah selanjutnya guna meningkatkan dan mengembangkan layanan yang sudah ada. Kebutuhan ini ditinjau berdasarkan desain layanan, kemudian dilanjutkan pada tahap operasional layanan yang sedang berjalan. Proses yang mencakup : Transition Planning and Support, Change Management, Service Asset \& Configuration Management, Release \& Deployment Management, Service Validation, Evalution, Knowledge Management.

Service Operation merupakan tahap untuk mencapai efektivitas dan efisiensi layanan, tahap ini meliputi kegiatan operasional harian yang bertanggung jawab atas pengelolaan dan pemeliharaan infrastruktur layanan TI secara keseluruhan.Proses yang mencakup: Event management, Incident Management, Problem Management, Request Fulfillment, Access Management.

Continual Service Improvement kegiatan peningkatan pelayanan secara berkesinambungan terhadap efektivitas dan efisiensi layanan TI. Memberikan panduan penting dalam menyusun serta memelihara kualitas layanan dari proses desain, transisi dan pengoperasiannya. CSI mengkombinasikan berbagai prinsip dan metode dari manajemen kualitas, salah satunya adalah PlanDo-Check-Act (PDCA) atau yang dikenal sebagai Deming Quality Cycle

\section{METODOLOGI PENELITIAN}

Dalam metodologi penelitian terdiri dari beberapa tahap seperti digambarkan di bawah ini.

Tahap 1 Dimulai dari identifikasi masalah yang merupakan proses dan pengenalan masalah yang akan menentukan kualitas suatu penelitian, bahkan juga menentukan apakah sebuah kegaiatan bisa disebut penelitian atau tidak.

Tahap 2 Tinjauan pustaka dan teori dimana pengkajian kembali literature-literatur yang relevan dengan penelitian yang sedang dikerjakan beserta teori - teori terdahulu sebagai acuan dalam penelitian, seperti masalah yang berkaitan atau tidak selalu harus tepat identic dengan permasalahan yang dihadapi, melainkan pula yang seiring dan berkaitan.

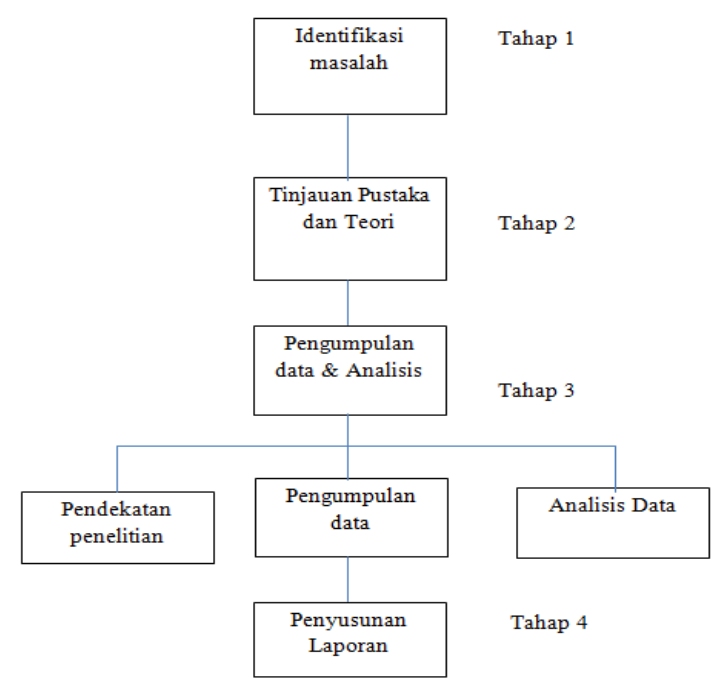

Gambar 1. Tahapan Penelitian

Tahap 3 Pengumplan data $\&$ analisis, dalam tahap ini terdapat 3:

1. Pendekatan penelitian dimana peneliti menggunakan pendekatan kualitatif yang menggambarkan secara kualitatif fakta, data atau objek material yang bukan berupa rangkaian angka, akan tetapi menggunakan bahasa atau wacana melalui interprestasi yang tepat dan tersusun secara sistematis dan ini merupakan prosedur penelitian yang menghasilkan data deskriptif berupa kata - kata tertulis atau lisan dari orang - orang dan perilaku yang dapat diamati.

2. Pengumpulan data dengan menggunakan observasi atau wawancara, observasi ini dilakukan untuk mendukung bukti - bukti yang telah diperoleh dari hasil wawancara, lalu diolah, disusun dan digambarkan kembali.

3. Analisis data didapatkan dari data mentah yang sudah diolah pada pengambilan data dan dianalisa menggunakan Framework ITIL V3 Domain Service Strategy. Peneliti menggunakan Domain Service Strategy dalam merancang mengembangkan dan menerapkan layanan TI, dalam domain tersebut terdapat proses - proses intinya diantaranya Service Portfolio, Financial Management, Demant Management.

1. Service Portfolio Management keterlibatan manajemen proaktif terhadap investasi diseluruh daur hidup layanan beserta pengelolaan dari konsep, desain, dan transisi layanan itu sendiri, sebagai jangkauannya seperti menentukan pengadaan layanan, menvalidasi, portofolio data, menganalisis supaya nilai 
portofolio maksimal, menyeimbangkan penawaran dan perminatnya, serta mengalokasikan sumber daya tersebut.

2. Financial Management seperti fungsi dan proses yang memiliki tanggung jawab mengelola keuangan, serta melakukan pencatatan transaksi dan persyaratan yang dibutuhkan.

3. Demand Management memiliki tujuan untuk memahami pengaruh permintaan pelanggan untuk layanan dan memberikan sarana agar terpenuhi permintaan tersebut.

Tahap 4 Penyusunan laporan merupakan informasi yang disampaikan secara tertulis atau lisan dengan tujuan untuk mengkomunikasikan kesimpulan hasil atau temuan peneliti beserta rekomendasi yang diperlukan

\section{HASIL DAN PEMBAHASAN}

Perusahaan Daerah Bank Perkreditan Rakyat Bank Bapas 69 Magelang adalah bank BUMD di Kabupaten Magelang, PD BPRP Bank Bapas 69 magelang didirikan tahun 1954 berdasarkan Peraturan Daerah Kabupaten Magelang No. 14/DPR tertanggal 28 April 1954. Perusahaan baru mulai kegiatan usaha secara keseluruhan sejak tahun 1969 berdasarkan Surat Keputusan Bupati Kepala Daerah Tingkat II Magelang No. 50/kd/69, tertanggal 9 September 1969, Surat Keputusan Bupati Kepala Daerah Tingkat II Magelang No. 43/PUB/69, tertanggal 19 September 1969, dan Anggaran Dasar/Peraturan Pendirian Bank Pasar No. 14/DPR/54. Kantor yang dimiliki oleh Bapas 69 Magelang ada 26, terdiri dari 1 Kantor Pusat, 3 Kantor Cabang dan 22 Kantor Kas.

Berikut adalah analisa Sistem Informasi Perkreditan Kantor Cabang Bapas 69 Magelang Selatan menggunakan ITIL V3 Domain Service Strategy.

Penggunaan layanan sistem informasi perkreditan pada Kantor Cabang Bapas 69 Magelang Selatan diperlukan untuk pengoperasian layanan perbankan. Menyediakan layanan ini telah diukur berdasarkan service level agreement yang kompetitif, pemicu produktivitas dan efisiensi kerja, maupun pengurangan resiko operasional. Maka untuk proses dalam strategi layanan pun perlu diperhatikan. Proses-proses dari strategi layanan itu sendiri sesuai ITIL V3 adalah layanan Service Portfolio Management, Financial Management, dan Demand Management.

\section{1) Service Portfolio Management}

Tujuan utama dari manajemen layanan portfolio adalah memberikan metode pengelolaan seluruh managemen layanan investasi demi membuat layanan teknologi informasi yang maksimal. Hasil pembahasan tentang analisa strategi layanan service secara menyeluruh, maka hasil yang diperoleh dilapangan untuk cakupan service portfolio management adalah SS 1 Introduction, SS
2 Service management as a practice, SS 3 Service strategy principles, SS 4 Service strategy dan SS 6 Strategy and organization.

SS 1 dan SS 2 telah diterapkan secara khusus dalam pengenalan strategi layanan teknologi dan sistem informasi perusahaan melalui diklat untuk dilakukan secara rutin pegawai hasil rekrutan, pendidikan pengembangan, pendidikan aplikasi, blue-print pendidikan untuk jajaran bisnis dan penunjang bisnis. Manajemen layanan sistem informasi perkreditan yang digunakan disesuaikan dengan aturan-aturan penyaluran kredit berdasarkan fungsi dan prosesnya. Secara khusus dalam kegiatan operasional sebagai praktek dari berbagai kebijakan dan aturan yang telah ditentukan guna memperoleh hasil yang menjadi tujuan utama perusahaan. Layanan sistem informasi perkreditan yang digunakan saat ini sudah sejalan dengan kebutuhan bisnis perusahaan. Tujuan jangka panjang tetap berfokus pada sektor usaha mikro, kecil dan menengah namun tetap memperhatikan sektor bisnis lainnya. Terutama dalam hal penyaluran kredit, aturan yang ada di sistem informasi perkreditan sesuai dengan aturan penyaluran kredit dari perusahaan. Dalam rangka mewujudkan tujuan jangka panjang pada perusahaan adalah melakukan prinsip-prinsip strategi layanan itu sendiri.

Prinsip strategi layanan dalam ITIL V3 yang terangkum dalam SS 3 yang mencakup kerangka kerja proses dalam layanan sistem informasi perkreditan, manajemen, portfolio dan keuangan. Pengadaan sistem informasi perkreditan pada Bapas 69 disertai perencanaan sumber daya yang matang dan prediksi keuntungan yang akan diperoleh dalam jangka waktu tertentu. Keuntungan yang diperoleh tidak hanya dalam bentuk uang akan tetapi dalam hal peningkatan efektivitas dan efisiensi kinerja karyawan, kepuasaan nasabah yang terlayani dengan cepat dan tepat, kepuasaan terhadap investasi di perusahaan, dan lainnya. Adanya sistem informasi di kantor cabang Bapas 69 Magelang Selatan sangat memberikan manfaat yang berarti ditengah besarnya tekanan bagi perusahaan untuk semakin meningkatkan kinerja dan kualitas pelayanan. Diawali dari pengurangan ketenaga kerjaan, pengurangan ini dianggap diperlu agar dapat mengurangi biaya untuk tenaga kerja, dengan harapan sistem informasi yang disediakan nantinya dapat memberikan dampak positif bagi kelangsungan kegiatan pelayanan kepada nasabah. Pengurangan pembiayaan untuk pengadan tenaga kerja yang sebelumnya membutuhkan tenaga kerja yang cukup banyak untuk melakukan aktivitas bisnis diperusahaan yang masih manual, dialihkan untuk pengadaan sistem informasi yang saat ini sedang dipakai. Dengan adanya sistem informasi yang secara terpadu memberikan kemudahan kepada pegawai selaku pelaku kegiatan operasional. Penentu cangkupan pemasaran yang terangkum dalam SS 4 ditetapkan oleh perusahaan dengan 
penuh pertimbangan. Dalam hal ini merujuk kepada sasaran pasar kredit Bapas 69 yaitu mikro, kecil dan menengah (UMKM) serta peluang bisnis lainnya.

Penilaian kapasitas dan kinerja sistem informasi perkreditan diperkirakan guna mengurangi resiko operasional, disamping itu perencanaan taktis pun selalu diperbaharui sesuai kebutuhan pasar. SS 6 Strategi dan organisasi merujuk kepada peran dan tanggung jawab para pegawai yang berinteraksi langsung dalam sistem informasi perkreditan. Otoritas pengguna diatur dalam hal akses data dan informasi agar mengurangi penyalahgunaan wewenang dan informasi. Sumber daya manusia menjadi asset penting dalam kelangsungan pemasaran bisnis, maka itu dengan sistem informasi perkreditan diharapkan dapat meningkatkan kinerja layanan Bapas 69 dan target yang ditetapkan oleh perusahaan terhadap setiap kantor cabangnya. Disamping itu Bapas 69 melaksanakan pengelolaan Sumber Daya Manusia (SDM) secara kesinambungan. Tahapan pengelolaan SDM diawali dari aktivitas planning, developing, retaining, dan maintaining, performance management dan terminating. Kantor Cabang Bapas 69 Magelang Selatan berusaha untuk selalu melakukan follow-up kepada setiap pegawai yang dianggap memiliki potensi yang dapat dikembangkan. Hal ini dapat dibukti adanya Diklat setahun sekali untuk dua orang setiap Kantor Cabangnya.Penerimaan calon pegawai Bapas 69 yang berasal dari displin ilmu memberikan keuntungan bagi perusahaan. Dengan adanya diklat diharapkan dapat memberikan pengetahuan yang baru kepada pegawainya dan kemudian pengetahuan itu dibawa ketempat kerjanya dan dibagikan kepada rekan-rekannya. Hal ini dianggap efektif dari segi pembiayaan, karena mengutus dua orang saja dari setiap Cabang tidak memakan biaya yang cukup besar. Dengan diadakan pendidikan dan latihan (diklat) pemeliharaan dan evaluasi setiap kantor cabang dapat dilakukan secara rutin. Hal ini dimaksudkan untuk memberikan pelayanan yang cepat dan tepat kepada nasabahnya.

\section{2) Financial Management}

Pada dasar manajemen keuangan diperlukan sebagai pijakan dalam pengalokasian dana dalam ketersediaan layanan teknologi informasi. Manajemen keuangan yang efektif diharapkan dapat memberikan suatu bukti jaminan layanan teknologi informasi yang mudah sesuai dengan keuntungan yang diharapkan oleh perusahaan atau organisasi. Untuk proses financial management dalam indeks ITIL V3 dari service strategy terangkum dalam SS 5 service economics yang membahas tentang layanan ekonomi dalam perencanaan strategis perusahaan, dalam hal pembiayaan dan pencatatan transaksi. Pengelolaan keuangan yang baik diharapkan dapat memberikan keuntungan dalam hal dana. Maka itu Kantor Cabang Bapas 69 Magelang Selatan menggunakan aturan limit kewenangan sesuai dengan jabatan pegawai, dimana besar kecil jumlah uang yang dapat digunakan oleh setiap pegawai disesuaikan dengan tugas dan tanggung jawabnya di dalam perusahaan, agar tidak terjadi kekeliruan dan pertanggung jawaban keuangan kedepannya.

Berdasarkan wawancara menunjukan bahwa manajemen keuangan dalam Kantor Cabang Bapas 69 Magelang Selatan telah ditangani dengan baik, Evaluasi pembiayaan dan keuntungan yang mendukung telah diperhitungkan dengan matang. Keuntungan yang didapat tidak hanya dari segi materi dalam bentuk uang, melainkan meningkatnya produktifitas kinerja pegawainya, kemudahan yang didapat dari sistem komputerisasi, serta pencapaian visi perusahaan dalam menjadi bank terkemuka yang mengutamakan nasabah. Dalam hal manajemen keuangan Kantor Cabang Bapas 69 Magelang Selatan bertanggung jawab sepenuhnya terhadap pengeluaran dan pemasukkan yang dihasilkan maupun dikeluarkan. Seperti pengadaan sistem informasi perkreditan ditangani langsung oleh Kantor Cabang sebagai cabang yang membutuhkan sistem informasi perkreditan tersebut. Sistem informasi yang diimplementasikan didiskusikan langsung dengan pihak vendor, Kantor pusat Bapas 69 melalui bagian IT hanya menjadi fasilitator dalam mensosialisasikan sistem informasi yang telah lulus uji coba. Maka itu Kantor Cabang Bapas 69 Magelang Selatan bertanggungjawab sepenuhnya terhadap penggunaan dana untuk pengadaan hingga implementasi sistem informasi perkreditan. Pembiayaan yang dibebankan kepada Kantor Cabang setempat diharapkan memberikan kemudahan dalam mencairkan dana. Perusahaan telah memprediksi secara detail dana yang dikeluarkan pada saat terjadi pengimplementasian dilakukan, sehingga berita acara yang dilaporkan ke Pusat pun haruslah sesuai dengan perkiraan tersebut, seperti tidak melambung jauh diatas perkiraan ratarata. Penggunaan dana untuk Cabang Bapas 69 Magelang Selatan secara keseluruhan dipantau dan dipertanggungjawabkan oleh Ka.Cab, sejauh ini belum ada permasalahan yang berarti didalam hal pertanggungjawaban keuangan. Berdasarkan wawancara yang diperoleh di lapangan, dapat dilihat bahwa perusahaan telah mengevaluasi pembiayaan dan keuntungan yang mengikutinya setelah diimplementasikannya sistem informasi perkreditan tersebut, tidak hanya sampai diimplementasinya. Pembiayaan untuk pemeliharaan dan dokumen secara. berkesinambungan harus terus dilakukan dan menjadi prioritas perusahaan dalam rangka meningkatkan kualitas pelayanan yang baik dan tepat.

\section{3) Demand Management}

Tujuan utama merupakan membantu menyediakan layanan, menyelaraskan penawaran dan permintaan yang yang dibutuhkan di dalam 
layanan teknologi informasi. Pengadaan layanan sistem informasi yang berlebih hanya akan membuang biaya dan tenaga, dan sebaliknya jika terjadi kekurangan pada sistem informasi operasi yang digunakan akan tidak sempurna dan tidak sesuai dengan kebutuhannya. Demand Management dalam indeks ITIL v3 mengenai service strategy memiliki indeks SS 7 Strategy, tactics and operation, SS 8 Technology and Strategy dan SS 9 Challenges, critical success factory and risks. SS 7 merupakan perencanaan strategis, taktis dan implementasi pada kegiatan terhadap teknologi dan sistem informasinya. Ukuran dan pengelolaan fungsi bisnis dan persyaratan teknis merupakan tolak ukur dalam perpindahan layanan sistem informasi.

Pengelolaan dan dokumentasi benar adanya dilakukan untuk menilai kualitas layanan secara berkala. SS 8 mengenai teknologi dan strategi secara langsung telah berjalan dengan baik, seperti dalam halnya penyaluran pinjaman. Pegawai diberikan kemudahan dengan menentukan jumlah pinjaman dan jangka waktu pelunasan, kemudian jumlah angsuran per bulan diperoleh dari jenis pinjaman yang diinginkan nasabah. Ketepatan waktu dalam angka dan penyesuaian suku bunga mudah dilakukan. Dan menjadi masalah adalah ketika sistem sedang downtime dan akhirnya jaringan menjadi offline, ini disebabkan oleh arsitektur jaringan Bapas 69 Magelang yang di buat secara terpadu dan mengakibatkan sistem offline selama beberapa jam saat server sedang maintance yang diakibatkan dari padatnya arus informasi dan transaksi yang dilakukan. Hal ini tidak menjadi masalah yang besar bila tidak mempengaruhi keuntungan perusahaan. SS 9 menganalisa tantangan, faktor sukses dan resiko yang akan dihadapi dalam sistem informasi perkreditan saat ini. Dalam menjaga kualitas portfolio perkreditan, Bapas 69 Magelang menerapkan prinsip kehatihatian dalam memberikan pinjaman, sejauh ini permintaan yang telah dipenuh oleh sistem informasi perkreditan menjawab kebutuhan pengguna dalam mempermudah proses penyaluran pinjaman, serta kebutuhan menganalisa dan menghitung nominal pinjaman, jangka waktu pelunasan dikaitkan dengan jumlah nominal angusran per bulan, dan lain sebagainya. Penerapan sistem informasi perkreditan dalam perusahaan dengan adanya kerangka kerja manajemen resiko untuk memberikan ulasan tantangan, faktor kesuksesan dan resiko dari hasil wawancara mendapatkan keterangan bahwa setidaknya perusahaan mengidentikasi dampak positive maupun negative dalam kegiatan operasional, jika sistem informasi perkreditan tidak sesuai dan tidak memenuhi kebutuhan, maka dapat dikembangkan lagi atau memperbaharui sistem informasi yang baru. Manajemen resiko selalu menangani dengan tepat, setiap masalah ditangani kepada bagian penanganan di Kantor Pusat.

\section{KESIMPULAN}

Berdasarkan hasil analisis dengan menggunakan framework ITIL V3 Domain Service Strategy beserta proses yang terjadi didalamnya, maka memiliki gambar kalau layanan sistem informasi perkreditan di Kantor Cabang Bapas 69 Magelang Selatan yang memiliki layanan yang dikelola dengan baik dan tepat, akan memberikan manfaat serta keuntungan yang berarti bagi kelangsungan aktifitas bisnis di perusahaan, Walaupun tidak semua keuntungan dapat dihitung dengan angka atau uang, seperti memudahkan proses pinjaman maupun pembayaran angsuran bulanan ditangani pada waktunya. Kemudian seperti Service Portfolio Managementyang memberikan pengenalan strategi layanan teknologi dan sistem informasi dalam pendukung bisnis pada perusahaan, memiliki prinsip strategi layanan untuk pengadaan system informasi perkreditan, dalam kegiatan pemasaran disasarkan kepada pasar kredit, kemudian merujuk pada aset sumber daya manusia dalam menggunakan sistem informasi lebih efektif. Financial Management dimana layanan ekonomi dalam perencanaan strategi memberikan jaminan bukti serta memberikan keuntungan untuk perusahaan atau organisasi. Demand Management memberikan suatu ukuran sebagai syarat teknis layanan sistem informasi yang dimiliki perusahaan dan menganalisa resiko yang ada dalam sistem informasi tersebut. Maka dari itu meskipun sistem informasi yang sudah dimiliki perusahaan sudah dikatakan sebagai layanan system informasi yang efektif akan tetapi harus dipelihara atau di kelola secara berkala untuk meminimalisir adanya resiko yang akan muncul. Maka dari itu pengelolaan sistem informasi harus di optimalkan tidak hanya untuk sementara saja, agar memiliki kesuksesan di dalam suatu organisasi atau perusahaan.

\section{DAFTAR PUSTAKA}

[1] Oktoviani, Manuputty, 2008. Analisis Sistem Informasi Perkreditan Menggunakan Framework ITIL V.3 Domain Service Strategi (service Portfolio Management, Financial Management dan Demand Management) di PT Bank Rakyat Indonesia (Persero) Tbk., Unit Beteleme. Repository Universitas Kristen Satya Wacana

[2] Utami, Darwiyanto, Asror, 2016. Audit Infrastruktur Teknologi Informasi dengan Standar Information Technology Infrastructure Library (ITIL) V.3 Domain Service Strategy dan Service Design (Studi Kasus : I-gracias)'”. Ind.Symposium on Computing Sept 2016. pp. 1-10

[3] Bata, Manuputty 2017. Analisis Layanan Manajemen Teknologi Informasi dengan Service Strategy ITIL V.3 (Studi Kasus: 
Fakultas Ilmu Kesehatan UKSW). Repository Universitas Kristen Satya Wacana

[4] Walingkas, Kapantow, Ruauw, 2016. Pemanfaatan Teknologi Informasi Dan Komunikasi Terhadap Usaha Jaring Ikan Di Desa Eris,Kecamatan Eris, Kabupaten Minahasa. Agri-sosioekonomi Volume 12 Nomor 2,Mei 2016 :1-14
[5] Haag dan Keen. 1996.Information Technology: Tomorrow's Advantage Today. Hammond: Mcgraw-Hill College.

[6] Surendro, Kridanto, 2009. Implementasi Tata Kelola Teknologi Informasi. Informatika Bandung 